\title{
Studies on some Drying Characteristics of Amla
}

\author{
Pankaj Minj $^{{ }^{*}}$, Kipoo Kiran Singh Mahilang ${ }^{2}$, John Diamond Raj ${ }^{1}$ \\ and Khilendra Sonboier ${ }^{1}$ \\ ${ }^{1}$ Department of APFE, SHIATS, Allahabad, UP, India \\ ${ }^{2}$ Department of FMP, SVCAET\&RS, IGKV, Raipur, CG, India \\ *Corresponding author
}

\begin{abstract}
A B S T R A C T
Keywords

Amla, Drying characteristics, Cost evaluation, Hot air oven, Cabinet tray dryer, Open sun drying

Article Info

Accepted:

17 January 2018

Available Online:

10 February 2018

A research work was carried out to determine the drying characteristics of amla using cabinet tray dryer and open sun drying as drying methods at Department of Food Process Engineering, SHIATS, Allahabad in the year 2015-2016. The variety of amla fruit taken for the study was Chakaiya. The final moisture contents of amla at $50^{\circ} \mathrm{C}, 60^{\circ} \mathrm{C}$, and $70^{\circ} \mathrm{C}$ for cabinet tray dryer was $2.69(\% \mathrm{db}), 2.38(\% \mathrm{db}), 2.22(\% \mathrm{db})$ respectively whereas for open sun drying it was $3.72(\% \mathrm{db})$. The time required to achieve the above levels of moisture content for amla were $25,21,16$ and $40 \mathrm{hr}$ in respective drying. The cabinet tray drying method required the lowest time, since the temperature of the dryer was constant $\left(70^{\circ} \mathrm{C}\right)$. The rate of drying was the highest in cabinet tray drying at $70^{\circ} \mathrm{C}$ is 8.19 to 0.72 $\left(\mathrm{min}^{-1}\right)$, followed by cabinet tray drying at $50^{\circ} \mathrm{C}$ is 5.19 to $0.46\left(\mathrm{~min}^{-1}\right)$, at $60^{\circ} \mathrm{C}$ is 6.78 to $0.55\left(\mathrm{~min}^{-1}\right)$ and in open sun drying is 1.26 to $0.29\left(\mathrm{~min}^{-1}\right)$ at similar climatic conditions. The cost of drying was maximum (Rs. $224.43 / \mathrm{kg}$ ) in case of cabinet drying at $50^{\circ} \mathrm{C}$ followed by cabinet drying at $60^{\circ} \mathrm{C}$ (Rs. $192.47 / \mathrm{kg}$ ), cabinet drying at $70^{\circ} \mathrm{C}$ (Rs. $152.52 / \mathrm{kg}$ ) and open sun drying (Rs.75.90/kg).
\end{abstract}

\section{Introduction}

Amla has a hallowed position in Ayurveda an Indian indigenous system of medicine. It belongs to the family of Euphorbiaceae that grows on Phyllanthus Emblica trees and is scientifically identified as Emblica officinalis (1).

The Annual production of Amla in India was 1319000 tonnes under an area of 107000 hectares and annual production of amla in Uttar Pradesh was 395870 tonnes under an area of 34970 hectares and in Allahabad it was 29580 tonnes under an area of 2710 hectares. (Horticultural Statistics at a Glance, 2015) (2).

The fresh or the dry fruit of amla are widely used in the Ayurvedic preparation, medicine, food, beauty industries and are believed to increase defence against diseases. It has beneficial role in degenerative disease like common cold, gastric troubles, bronchitis, headache, cough, asthma, constipation, enlarged liver, cancer, ophthalmic disorders, dyspepsia, colic, flatulence, skin diseases, leprosy, jaundice, scurvy, diarrhea, grayness 
of hair, diabetes, ulcer, anemia, heart trouble and also is an important constituent in hepatoprotective formulas available. It is very effective in shedding weight when supplemented by good diet, nutritional supplements and a healthy lifestyle (3).

Most of the research work on Amla is related to the nutritive value of the fresh fruit and its products but little information is available regarding the dehydration of fruits and storage quality of dried Amla. Fresh Amla offers a serious problem during storage, transport and marketing because of its high perishable nature. Amla has many functions including medicinal, but the moisture content of the Amla is a problem decreasing the shelf life of amla. The high moisture content of amla causes insect and pest attack or yeast and mould growth and it is decayed or spoiled. Drying is considered as one of the best preservation methods to increase the shelf life of amla and also to overcome from all the above problems which is stated above (4).

\section{Materials and Methods}

\section{Physical properties of amla}

\section{Average length (L) and width (W)}

To determine the size and shape of the amla, a sample of 10 fruits were randomly picked.

The dimensions along three perpendiculars mutually axes of the amla was measured with a Vernier caliper to an accuracy of $0.01 \mathrm{~mm}$. The Average length (L) and width (W) was calculated by using the following relationship 2.1 and 2.2 (Mohsenin, 1986).

$$
\begin{aligned}
& \mathbf{L}=\frac{\sum_{i=1}^{n} \mathrm{~L}}{n} \ldots \\
& \mathbf{W}=\frac{\sum_{i=1}^{n} \mathrm{w}}{n} \ldots
\end{aligned}
$$

Where,

$\mathrm{L}=$ Major diameter (length), $\mathrm{mm}$; and

$\mathrm{W}=$ Intermediate diameter (width), $\mathrm{mm}$.

\section{Determination of moisture content}

Moisture content of the amla slices was calculated by the following formula.

$\operatorname{MC}(\mathrm{db})=\left(\mathrm{M}_{\mathrm{w}} \div \mathrm{M}_{\mathrm{d}}\right) \times 100 \quad \ldots(2.3)$

Where,

MC $(\mathrm{db})=$ Moisture content, percent (dry basis),

$\mathrm{M}_{\mathrm{w}}=$ Mass of water $(\mathrm{g})$, and

$\mathrm{M}_{\mathrm{d}}=$ Mass of dry matter $(\mathrm{g})$.

\section{Determination of drying rate}

Drying rate of the amla slices at any time was calculated by the following formula.

$\mathrm{R}=\left(\mathrm{W}_{\mathrm{r}} \div\left(\mathrm{T} \times \mathrm{W}_{\mathrm{d}}\right)\right) \times 100 \quad \ldots(2.4)$

Where,

$\mathrm{R}=$ Drying rate $\left(\mathrm{min}^{-1}\right)$,

$\mathrm{W}_{\mathrm{r}}=$ Amount of moisture removed $(\mathrm{g})$,

$\mathrm{T}=$ Time of drying ( $\mathrm{min})$, and

$\mathrm{W}_{\mathrm{d}}=$ Total bone dry weight of sample $(\mathrm{g})$.

\section{Cost evaluation}

Fixed cost $=$ Depreciation+Interest + miscellaneous (Housing and insurance) ... (2.5)

Depreciation $=(\mathrm{P}-\mathrm{S}) \div(\mathrm{N} \times \mathrm{L}) \quad \ldots(2.6)$

Interest $=((\mathrm{P}+\mathrm{S}) \div 2) \times(\mathrm{R} \div 100) \times(1 \div \mathrm{N})$ ... (2.7)

Where,

$\mathrm{P}=$ Investment cost,

$\mathrm{L}=$ Expected life,

$\mathrm{N}=$ Hourly use per year,

$\mathrm{S}=$ Salvage value,

$\mathrm{R}=$ Interest.

Variable cost $=$ Labour cost + Repair and 
maintenance cost + Electricity cost. ... (2.8)

Total cost (per $\mathrm{kg}$ of dried product $)=$ fixed cost + variable cost + material cost. . .. (2.9)

Net profit (per $\mathrm{kg}$ ) $=$ Cost of processed product - Total cost. ... (2.10)

\section{Results and Discussion}

\section{Physical properties of amla}

The variety of amla fruit taken for the study was Chakaiya and it tends to be flattened round in shape. The average length and width of fruit was measured to be 3.40 and $4.10 \mathrm{~cm}$ respectively. The average weight of fruit was measured to be $30.66 \mathrm{~g}$. Table 1 shows the physical properties of amla fruit.

\section{Drying characteristics of amla}

Amla were dried using two methods viz., cabinet dryer at a temperature of at $50^{\circ} \mathrm{C}$, at $60^{\circ} \mathrm{C}$, at $70^{\circ} \mathrm{C}$ and open sun drying. The drying characteristics of amla under different drying methods are summarized below.

\section{Change in moisture content of amla with drying time}

The drying behavior of amla in different drying methods has been presented in Figure 1 as a plot of moisture content versus time of exposure. The maximum drying temperature was achieved during the period of 12 to 2.00 $\mathrm{pm}$ for the sun drying whereas the cabinet dryer was set at $50^{\circ} \mathrm{C}, 60^{\circ} \mathrm{C}$ and $70^{\circ} \mathrm{C}$ throughout the drying period. Final moisture content for different drying methods at $50^{\circ} \mathrm{C}$ is $2.69(\% \mathrm{db})$, at $60^{\circ} \mathrm{C}$ is $2.38(\% \mathrm{db})$, at $70^{\circ} \mathrm{C}$ is $2.22(\% \mathrm{db})$ in cabinet dryer and in open sun drying is $3.72(\% \mathrm{db})$. The final weight of amla sample in cabinet drying at $50^{\circ} \mathrm{C}$ is $12.96 \mathrm{~g}$, at $60^{\circ} \mathrm{C}$ is $12.92 \mathrm{~g}, 70^{\circ} \mathrm{C}$ is $12.90 \mathrm{~g}$ and in open sun drying is $13.09 \mathrm{~g}$. When drying time is increases the moisture content is decreased due to when drying time is increases then the moisture of amla gets removing that's why the moisture content of amla decreases. The time required to achieve the final moisture content were 1500 minutes at $50^{\circ} \mathrm{C}, 1260$ minutes at $60^{\circ} \mathrm{C}, 960$ minutes at $70^{\circ} \mathrm{C}$ for cabinet drying and 2400 minutes for open sun drying of amla in respective drying.

\section{Change in drying rate of amla with drying time}

The drying characteristics of the amla were also evaluated on the basis of drying rate in different methods. It can be seen that as the drying time increased the drying rate decreased. The rate was higher at the beginning of the process, which gradually reduced as the drying process progressed and the availability of moisture was reduced. The drying rate for different drying methods at $50^{\circ} \mathrm{C}$ is 5.19 to $0.46\left(\mathrm{~min}^{-1}\right)$, at $60^{\circ} \mathrm{C}$ is 6.78 to $0.55\left(\mathrm{~min}^{-1}\right)$, at $70^{\circ} \mathrm{C}$ is 8.19 to $0.72\left(\mathrm{~min}^{-1}\right)$ and in open sun drying is 1.26 to $0.29\left(\mathrm{~min}^{-1}\right)$. When drying time is increases the drying rate is decreased due to duration of drying time increased the amount of moisture losses is also increases that's why drying rate decreases. Figure 2 presents the Change in drying rate Vs drying time for cabinet drying and open sun drying methods

\section{Change in drying rate of amla with moisture content}

The variation of drying rate with moisture content under different drying methods is shown in Figure 3. It can be seen that the drying rate decreases as the moisture content of the amla decreases. This was fact because the availability of moisture for the drying reduced with the time of drying which eventually reduced the rate of drying. As already said the highest drying rate was observed in case of cabinet drying at $70^{\circ} \mathrm{C}$ 
and was lowest for the open sun drying. Efforts have been made to correlate the drying rate with the moisture content of the amla (Fig. 4 and 5).

\section{Cost economics of different drying methods}

Cost economics of drying of amla in cabinet drying and open sun drying was estimated.
This cost economics shows that the cost of drying was maximum (Rs. $224.43 / \mathrm{kg}$ ) in case of cabinet drying at $50^{\circ} \mathrm{C}$ followed by cabinet drying at $60^{\circ} \mathrm{C}$ (Rs. $192.47 / \mathrm{kg}$ ), cabinet drying at $70^{\circ} \mathrm{C}$ (Rs. $152.52 / \mathrm{kg}$ ) and open sun drying (Rs. $75.90 / \mathrm{kg}$ ). The net saving of Rs. 74.10 per $\mathrm{kg}$ of processed product was recorded for open sun drying.

Table.1 Shows the physical properties of chakaiya variety of amla

\begin{tabular}{|l|l|l|l|l|l|l|}
\hline $\begin{array}{l}\text { Fruit } \\
\text { variety }\end{array}$ & $\begin{array}{l}\text { Fruit } \\
\text { length } \\
\text { (cm) }\end{array}$ & $\begin{array}{l}\text { Fruit } \\
\text { width } \\
\text { (cm) }\end{array}$ & $\begin{array}{l}\text { Fruit } \\
\text { weight } \\
\text { (g) }\end{array}$ & $\begin{array}{l}\text { No of } \\
\text { segments/ } \\
\text { fruit }\end{array}$ & $\begin{array}{l}\text { Fruit } \\
\text { size }\end{array}$ & Fruit shape \\
\hline Chakaiya & 3.40 & 4.10 & 30.66 & 6 & Medium & Flattened round \\
\hline
\end{tabular}

Fig.1 Change in moisture content Vs drying time for cabinet drying and open sun drying methods

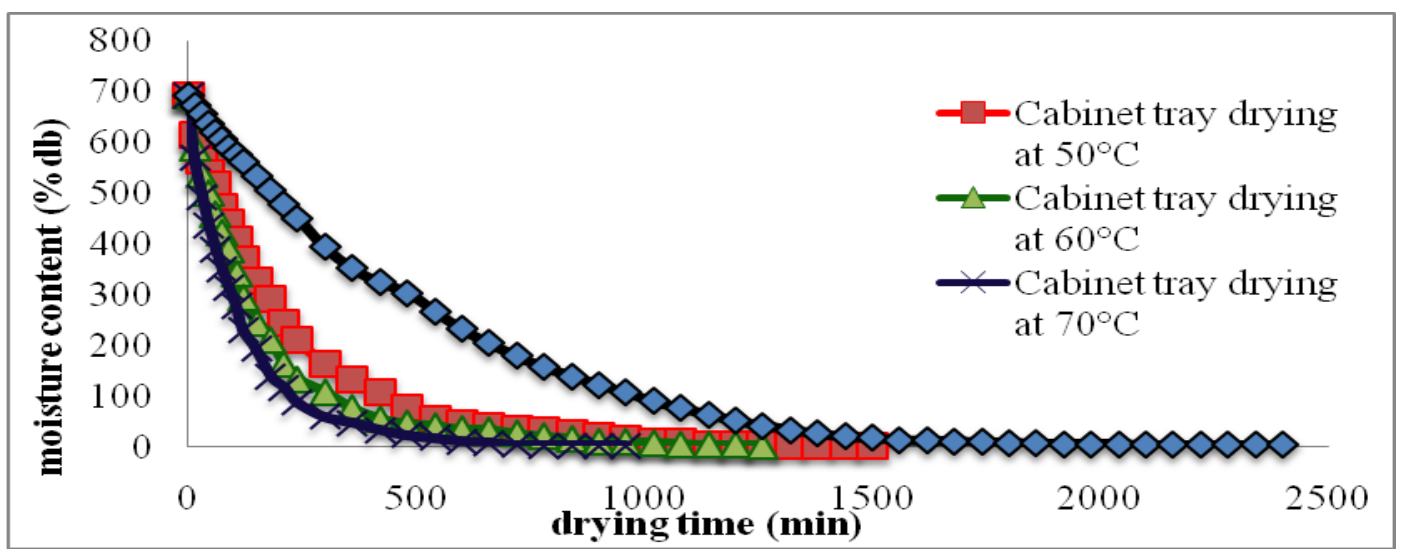

Fig.2 Change in drying rate Vs drying time for cabinet drying and open sun drying methods

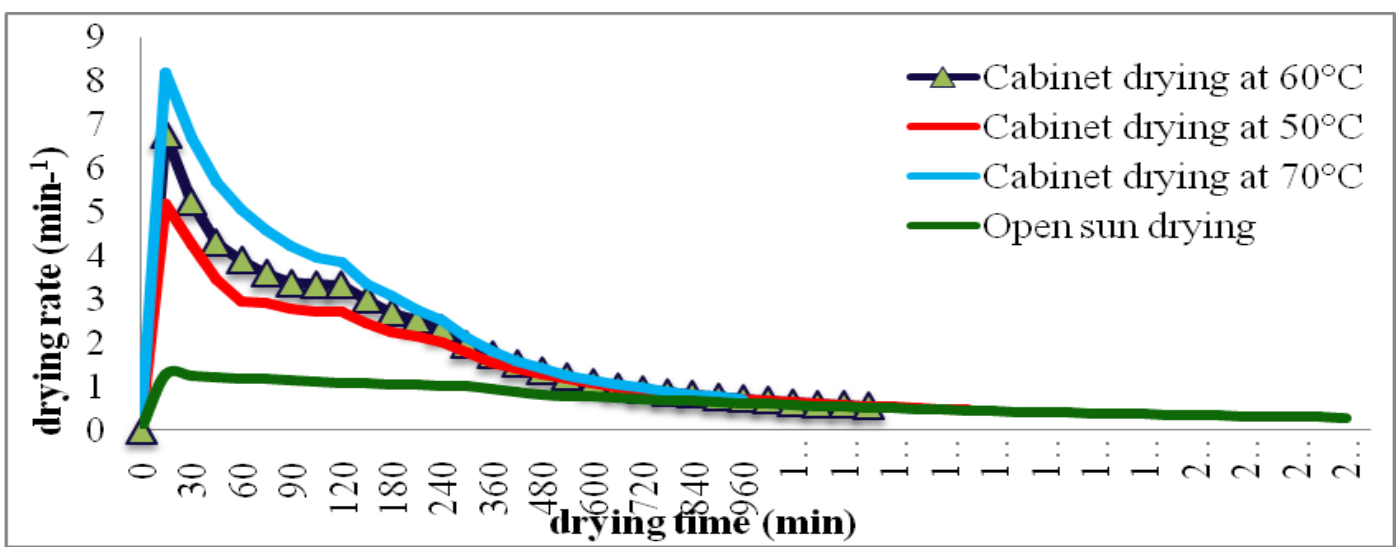


Fig.3 Change in moisture content Vs drying rate for cabinet drying and open sun drying methods

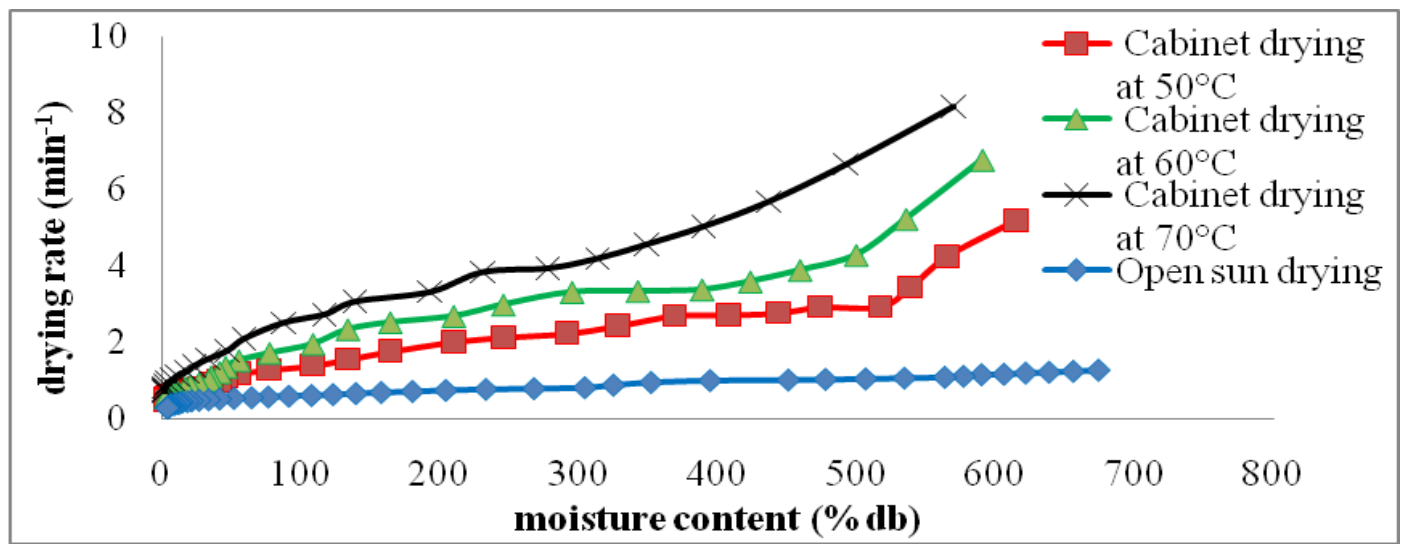

Fig.4 Dried amla sample after cabinet drying at $50^{\circ} \mathrm{C}, 60^{\circ} \mathrm{C}$ and $70^{\circ} \mathrm{C}$

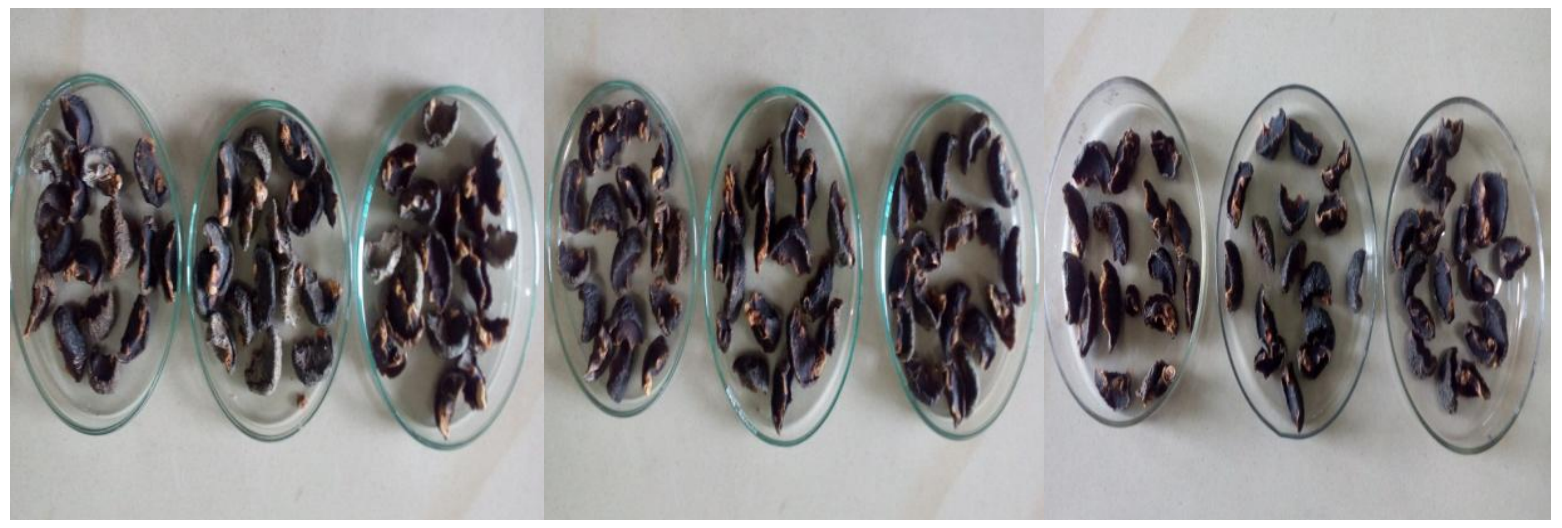

Fig.5 Dried amla sample after open sun drying

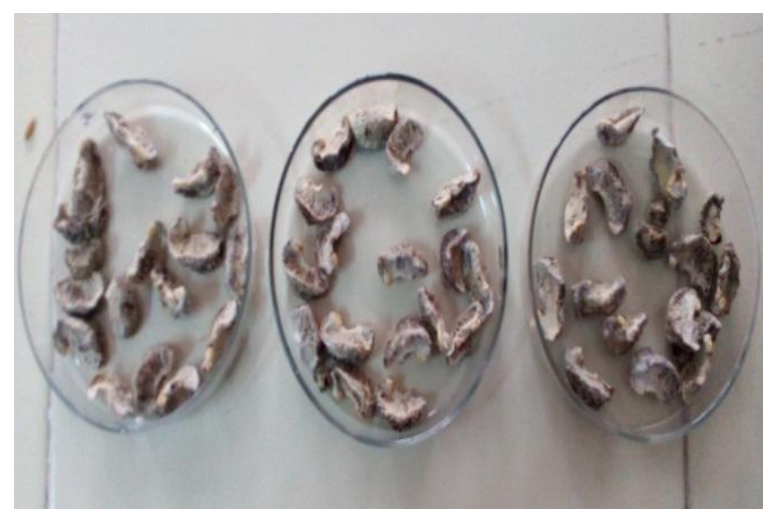

In conclusion, the advantages of Sun drying have simplicity and the small capital investment. But, there are many technical problems which are uncertainties like rain and cloudiness, contamination from outer sources and lack of control over drying conditions. It 
requires large areas and long drying time. The final product may be contaminated from dust and insects and suffer from enzyme and microbial activity. It is limited to climates with hot sun and dry atmosphere with strong winds. Cabinet tray drying was found to be better over open sun drying in respect of Final moisture content, rate of drying, drying time moisture evaporation, as they required lesser time. Open sun drying is more profitable compared to cabinet drying. However cabinet dryer was found to be uneconomical for drying of $1 \mathrm{~kg}$ amla slices. Thus cabinet drying can be preferred over the sun drying method.

\section{References}

1. Akhtar, M. S., Ramzan, A., Ali, A. and Ahmad, M. 2011. Effect of amla fruit (Emblica officinalis Gaertn.) on blood glucose and lipid profile of normal subjects and type 2 diabetic patients. Int. J. Food. Sci. Nutr.

2. Ahmad, J., Mehmood, Z. and Mohammad, F. 1998. Screening of some Indian medicinal plants for their antimicrobial properties. Journal of Ethanopharmacology. 62, 183-193.

3. Chadha, K. L. 2003. Handbook of horticulture. New Delhi: ICAR Publications.

4. Chowdhury Amina Parvin 2013.
Degradation of vitamin C during drying and storage of amla (Emblica Officinalis) and development of pickles from amla. MS Thesis. Department of Food Technology and Rural Industries, Bangladesh Agricultural University, Mymensingh.

5. Deokar, A.B., 1998. Medicinal Plants Grown at Rajegaon, first ed. DS Manav Vikas Foundation, Pune, pp. 48-49.

6. Horticultural Statistics at a Glance, 2015. Horticulture statistics division, department of agriculture, cooperation \& farmers welfare ministry of agriculture \& farmers welfare government of India. Page- 17, $177,259$.

7. Krishnaveni, M. and Mirunalini, S. 2011. Amla - The role of Ayurvedic therapeutic herb in cancer. Asian J. Pharm. Clin. Res., 4 (3) 13-17.

8. Minj, P. Studies on drying characteristics of amla. M. Tech. Thesis, SHIATS, Allahabad; 2016.

9. National Horticulture Board. http://nhb. gov.in/report_files/aonla/AONLA.htm.

10. Rege, N. N., Thatte, U. M. and Dahanukar, S. A. 1999. Adaptogenic properties of six rasayana herbs used in Ayurvedic medicine. Phytotherapy Research. 13, 275-291.

11. Singh, V., Singh, H. K. and Chopra, C. S. 2005. Studies on processing of aonla (Emblica officinalis Garten) fruits. Beverage and Food World, 32(12): 50-52.

\section{How to cite this article:}

Pankaj Minj, Kipoo Kiran Singh Mahilang, John Diamond Raj and Khilendra Sonboier. 2018. Studies on some Drying Characteristics of Amla. Int.J.Curr.Microbiol.App.Sci. 7(02): 21132118. doi: https://doi.org/10.20546/ijcmas.2018.702.252 